\title{
Role of the Digestive Gland in Ink Production in Four Species of Sea Hares: An Ultrastructural Comparison
}

\author{
Jeffrey S. Prince and Paul Micah Johnson \\ Dauer Electron Microscopy Laboratory, Department of Biology, University of Miami, Coral Gables, FL 33124, USA \\ Correspondence should be addressed to Jeffrey S. Prince; jeffprince@miami.edu
}

Received 25 June 2013; Accepted 20 October 2013

Academic Editor: Nobuyuki Miyazaki

Copyright (C) 2013 J. S. Prince and P. M. Johnson. This is an open access article distributed under the Creative Commons Attribution License, which permits unrestricted use, distribution, and reproduction in any medium, provided the original work is properly cited.

\begin{abstract}
The ultrastructure of the digestive gland of several sea hare species that produce different colored ink (Aplysia californica produces purple ink, A. juliana white ink, A. parvula both white and purple ink, while Dolabrifera dolabrifera produces no ink at all) was compared to determine the digestive gland's role in the diet-derived ink production process. Rhodoplast digestive cells and their digestive vacuoles, the site of digestion of red algal chloroplast (i.e., rhodoplast) in A. californica, were present and had a similar ultrastructure in all four species. Rhodoplast digestive cell vacuoles either contained a whole rhodoplast or fragments of one or were empty. These results suggest that the inability to produce colored ink in some sea hare species is not due to either an absence of appropriate digestive machinery, that is, rhodoplast digestive cells, or an apparent failure of rhodoplast digestive cells to function. These results also propose that the digestive gland structure described herein occurred early in sea hare evolution, at least in the common ancestor to the genera Aplysia and Dolabrifera. Our data, however, do not support the hypothesis that the loss of purple inking is a synapomorphy of the white-ink-producing subgenus Aplysia.
\end{abstract}

\section{Introduction}

The release of bright purple ink from the ink glands of many species of sea hares (Gastropoda: Opisthobranchia: Anaspidea) is a major component of their defensive arsenal against predators [1-4]. Though all sea hares possess ink glands in their mantle cavities, not all of these glands release purple ink and, in fact, some release no ink at all [3].

Ink released by sea hares is a mixture of compounds from two glands, the ink and opaline glands $[3,5]$. That released from the ink gland has two major components: aplysioviolin (APV) which is $65 \%$ of the dry weight of the bright purple ink released by the best studied ink producing sea hare, Aplysia californica Cooper [6], and a high molecular mass protein that has been named escapin $[7,8]$. APV is derived from the red algal photosynthetic pigment, r-phycoerythrin (PE), minus its low molecular mass protein. This produces phycoerythrobilin (PEB) that is then methylated in the ink gland to form APV $[6,7,9-13]$. APV may be a better storage form of red algal pigment than PEB and this could account for the conversion of PEB to APV. Escapin, like similar high molecular mass protein from related sea hare species, is capable of producing antipredator responses as well as provide both antimicrobial and antitumor activity ([4], see [14] for a review). This ink protein appears to be synthesized in the RER cells of the ink gland [14]. Additional compounds in ink released from the ink gland produce a powerful feeding response, phagomimicry $[4,7,15]$.

The colored component of ink is, therefore, diet derived. But one sea hare species, Dolabrifera dolabrifera Cuvier, is incapable of producing colored ink regardless of diet. Aplysia juliana Quoy and Gaimard, a green-algal-feeding sea hare, produces purple ink only when restricted to a diet containing PE [14] while a third species, A. parvula Guilding in Morch, 1863, produces both white and purple ink (Johnson pers. obs.). The source of PE in A. californica is the red algal chloroplast (or rhodoplast), which is catabolised in digestive vacuoles in a specialized cell type, the rhodoplast digestive cell, in the animal's digestive gland. The rhodoplast digestive cell is a morphologically distinct cell type in the digestive gland of A. californica [16]. Immunogold electron microscopy for PE found that removal of the low molecular weight protein from the chromophore (thus forming PEB) occurs in the digestive vacuoles of the rhodoplast digestive cell and nowhere else 
$[12,16]$. As described above, Kamio et al. [13] show that PEB is then converted to APV in the ink gland. PEB, however, appears to be the pigment form in other areas of the body particularly the skin [13].

The presence of rhodoplast digestive cells appears, therefore, to be necessary for the production of colored ink in A. californica. The presence of rhodoplast digestive cells, however, has only been verified for this sea hare species [16]. We studied the digestive gland of several sea hare species to answer the following questions. (1) Is the lack of production of colored ink in D. dolabrifera due to the absence of appropriate digestive machinery, that is, rhodoplast digestive cells in its digestive gland? (2) Do rhodoplast digestive cells appear in the digestive gland of a white inking, green algal-feeding species, A. juliana, only when on a red algal diet or are they always present? (3) Finally, are rhodoplast digestive cells also found in the digestive gland of $A$. parvula, which produces both white and purple ink and, if so, do they have a similar ultrastructure to those found in A. californica?

\section{Materials and Methods}

2.1. Animal Collection. Individuals of Aplysia californica, 100 to $200 \mathrm{~g}$ wet mass, were obtained from the National Resource for Aplysia, University of Miami, while Dolabrifera dolabrifera, about $30 \mathrm{~g}$ wet mass, was collected from a sea table at the Hawaii Institute of Marine Biology, Kaneohe, Hawaii. Dolabrifera dolabrifera was transferred to a seawater tank at Windward Community College (WCC), Kaneohe, Hawaii, until being sent to Miami three months later. While at WCC it was fed daily with nori, containing Porphyra sp., but was also able to graze on resident algae, which included filamentous greens and coralline reds. Aplysia juliana and Aplysia parvula, each about $40 \mathrm{~g}$ wet mass, were field collected from several sites on the Noto Peninsula, Ishika Prefecture, and near the Seto Marine Biological Laboratory, Wakayama Prefecture, Japan. Aplysia juliana was feeding on the green algae, Ulva and Enteromorpha spp., while A. parvula was feeding almost exclusively on the red alga, Portieria hornemannii Lyngbye. Information on the digestive gland of $A$. californica comes from a previous study [16].

2.2. Ultrastructure. Tissue isolation for electron microscopy was done according to Prince [17] and Prince et al. [18]. In brief this involved fixing the tissue in $2.5 \%$ glutaraldehyde in half-strength Millonig's phosphate buffer, $\mathrm{pH} 7.3$, for $2 \mathrm{~h}$ at room temperature, postfixed in $1 \% \mathrm{OsO}_{4}$ for $1.5 \mathrm{~h}$, dehydrated in an ethanol series, and embedded in LR White resin. Thin sections were viewed with a Philips 300 electron microscope at $60 \mathrm{KV}$ or a JEOL 1400 electron microscope at $80 \mathrm{KV}$ after the sections were stained with lead citrate and uranyl acetate. In some cases uranyl acetate was omitted to reveal calcium carbonate deposits. Measurements employed Image J for Mac.

\section{Results}

Rhodoplast digestive cells were found in the digestive glands of all species studied (Figures 1(a), 1(d), 1(e), 1(g), and 1(h)).
The traits that characterize this cell type in A. californica [16] also distinguished these cells in the other species: a large cell with an enlarged nucleus, dense cytoplasm with numerous mitochondria, conspicuous endoplasmic reticulum, and several vacuoles, each with a single rhodoplast in various stages of digestion.

The appearance and diameter of the phycobilisome sized particles (Figure 1(c)) in rhodoplast digestive cell vacuoles of D. dolabrifera (mean diameter $\pm \mathrm{SD}=34.6 \pm 5, n=24$ ) were similar to those found in rhodoplast digestive cell vacuoles of A. californica (mean diameter $\pm \mathrm{SD}=37.1 \pm 5, n=40$; Coelho et al. [16]).

Aplysia juliana had large pitted electron dense granules in cells adjacent to rhodoplast digestive cells (Figure 1(b)). Medium osmophilic granules were also found in the rhodoplast digestive cells or cells adjacent to them, and these appeared to be starch grains (Figures 1(a), and 1(b)).

Calcium carbonate deposits were found only in the digestive gland of $D$. dolabrifera. These deposits appeared to develop in cells that contained several, frequently irregular, small vacuoles filled with calcium carbonate (Figure $1(\mathrm{~g})$ ). The vacuoles appeared to coalesce into a single, progressively larger granule to the point that the cell consisted of a nucleus and a thin layer of cytoplasm surrounding the calcium granule (Figure 1(f)). The cell membrane was not modified into pore or sieve-like areas. When stained with uranyl acetate the calcium deposit appeared to have a submatrix of electron dense, globular material (Figures 1(f) and 1(h)).

\section{Discussion}

The inability to produce colored ink by several species of sea hare could be due to several factors: (1) the absence of the rhodoplast digestive cell type in the digestive gland (this is the principal cell involved with red algal chloroplast digestion and modification of its pigment $[12,13,16])$; (2) the development in some sea hares of rhodoplast digestive cells only when feeding on red algae; (3) a diet preference that is deficient in red algae and its pigment; and, finally, (4) ink glands that are incapable of ink production regardless of rhodoplast digestive cell presence or the algal diet of the sea hare. In addition, (5) does colored ink production in sea hare species other than A. californica involve rhodoplast digestive cells in their digestive gland? Our results suggested, furthermore, which traits characterized the digestive gland in the most recent common ancestor to this genus and its sister group, Dolabrifera.

4.1. Rhodoplast Cells. To answer the first two questions above, the digestive gland of four sea hare species with a range in the type of ink produced was studied. Aplysia californica produces purple ink, $A$. parvula releases both white and purple ink, A. juliana makes white ink but can also produce purple ink when fed red algae, while $D$. dolabrifera does not produce any ink regardless of diet. We found, however, that all four species had (1) rhodoplast digestive cells in their digestive glands and (2) rhodoplast digestive cells that appeared to be involved ultrastructurally with the digestion of rhodoplasts since fragments of rhodoplasts were found in 


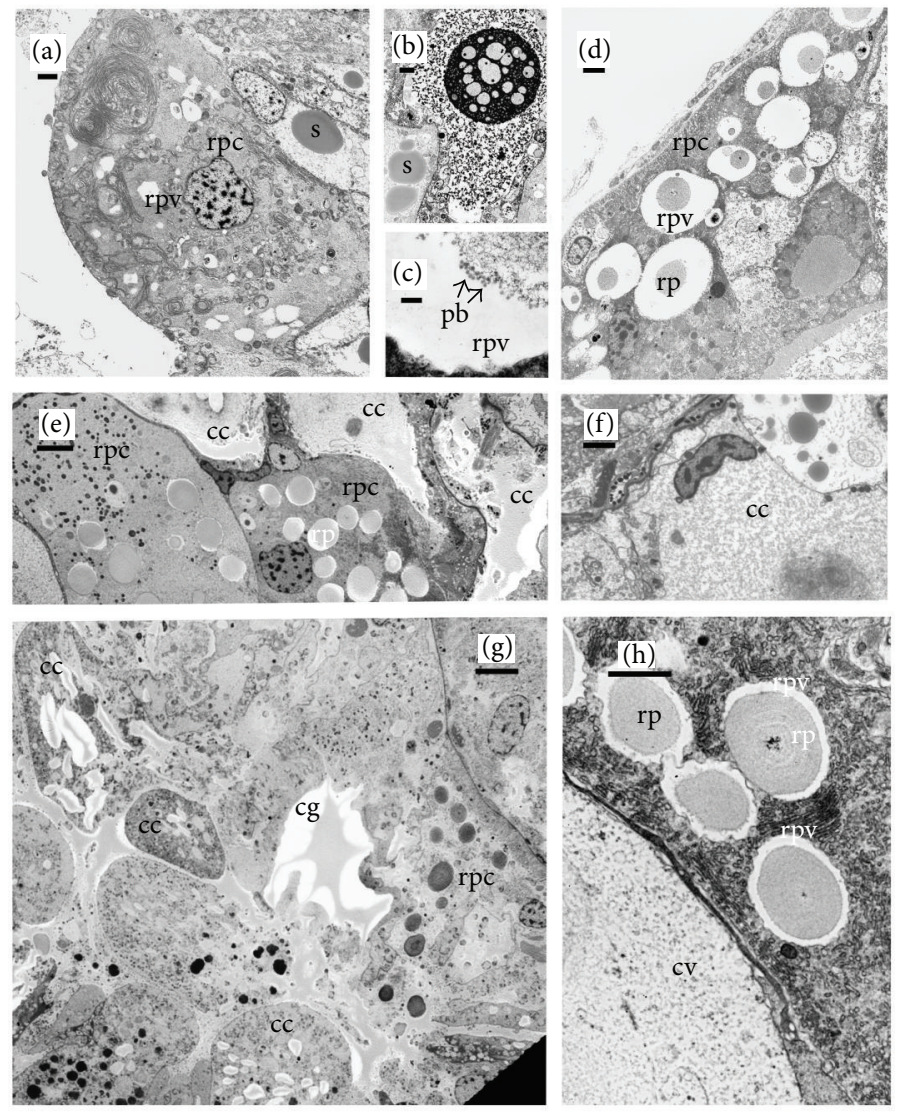

Figure 1: Digestive glands of Aplysia juliana ((a), (b)), Aplysia parvula (d), and Dolabrifera dolabrifera ((c), (e)-(h)). ((a) and (b)) Rhodoplast cell with mainly empty digestive vacuoles and adjacent medium osmophilic granules and large electron-dense granule (compare with [16] Figure 7(a, c)). (c) Rhodoplast digestive vacuole with phycobilisome sized particles (compare with [16] Figure 4(d)). (d) Rhodoplast cell with full digestive vacuoles. (e) Rhodoplast cells with adjacent calcium carbonate granules and (f) a portion of a calcium carbonate cell showing the location of the nucleus. (g) Mature and immature calcium cells with adjacent rhodoplast cells and (h) the whorled appearance of rhodoplasts in rhodoplast cell digestive vacuoles (compare with [16] Figure 4(b, d)) adjacent to a calcium carbonate deposit. cc: calcium cell; cg: calcium carbonate granule; cv: calcium vacuole; pb: phycobilisome; rp: rhodoplast; rpc: rhodoplast cell; rpv: rhodoplast vacuole; s: starch. Scale bars: (a), (d), (f), and (h) $=2 \mu \mathrm{m}$; (b) $=4 \mu \mathrm{m}$; (c) $=0.2 \mu \mathrm{m}$; (e) and (g) $=5 \mu \mathrm{m}$.

their digestive vacuoles. The presence of rhodoplasts in rhodoplast digestive cell vacuoles of all four sea hare species also suggested that an appropriate dietary precursor, red algae, was available for colored ink production in all four species.

The lack of production of colored ink by $D$. dolabrifera did not, therefore, appear to be due to either the absence of rhodoplast digestive cells in the digestive gland or a lack of rhodoplasts in their digestive vacuoles. In addition, phycobilisome-sized particles were observed in the digestive vacuoles of rhodoplast digestive cells of $D$. dolabrifera just as they had been for A. californica [16]. This suggested that rhodoplast digestive cells in $D$. dolabrifera were involved in the digestion of both rhodoplasts and their phycobilisomes. But the presence of rhodoplast digestive cells and phycobilisomes in the digestive gland of $D$. dolabrifera does not indicate whether or not the rhodoplast cells were also involved with the modification of $\mathrm{PE}$, an alteration that does occur in A. californica.

4.2. Inability to Form Colored Ink. Dolabrifera dolabrifera does not produce colored ink even though rhodoplast digestive cells were present in its digestive gland and appeared to be involved in the digestion of rhodoplasts. In addition, granulate cells in the ink gland of $D$. dolabrifera lacked dense granules [14]. Such granules in the ink gland of A. californica consist of stored, excess pigment $[12,14]$ probably as aplysioviolin (APV, 14). Granules were also absent from granulate cells when $A$. californica was restricted to a green algal diet [12].

The lack of pigment storage granules in granulate cells in the ink gland and the inability to form colored ink by D. dolabrifera suggested that a red algal food either was not available or was not being metabolized. But abundant rhodoplast digestive cells with rhodoplasts in various stages of digestion were seen in the digestive gland of $D$. dolabrifera fed a red algal diet. This implied that the rhodoplast digestive cell, in particular the digestive vacuoles in this cell type, was not functioning in a fashion similar to those in A. californica, particularly the removal of the low molecular weight protein from the chromophore $[12,13]$. Perhaps the protein component of phycoerythrin must be removed before the chromophore (PEB) can be transported by the hemolymph 
or before it can be taken up by granulate (to form dense granules) or vesicle cells (to form purple vesicles). Coelho et al. [16] found that absorption spectra for both PE and PEB were present in the hemolymph of $A$. californica fed red algae but were absent from the hemolymph of $A$. californica restricted to a diet of romaine lettuce.

Lack of colored ink production by $D$. dolabrifera might also be due to an ink gland that can not form ink regardless of diet or the presence of functional rhodoplast digestive cells in the digestive gland. Prince and Johnson [14] suggest that the lack of production of a high molecular weight, antipredator ink protein (similar to escapin in A. californica) by the ink gland of $D$. dolabrifera is caused by the presence of ultrastructurally different rough endoplasmic rich (RER) cells in its ink gland versus these cells in A. californica. But the ultrastructure of granulate cells in both sea hare species was identical except for the lack of pigment granules in $D$. dolabrifera. The ultrastructural difference of RER cells, therefore, suggests that the ink gland is incapable of forming the protein component of ink but the ultrastructural similarity of granulate cells in the two species suggests that they both should be able to form the colored component of ink.

Kamio et al. [13] suggest that methylation of phycoerythrobilin (PEB) to form aplysioviolin(APV) occurs in either or both the vesicle cells and granulate cells in the ink gland. Perhaps D. dolabrifera cannot methylate PEB in either cell type and thus is not able to form colored ink even though the machinery for colored ink production in both the digestive and ink glands has a similar ultrastructure.

4.3. Diet and Colored Ink Production. Production of purple vesicles by $A$. juliana when this sea hare is restricted to a red algal diet did not involve the reappearance of rhodoplast cells in the digestive gland; they were always present. This indifferent response to a green or red algal diet is supported by growth of $A$. californica. Aplysia californica on a red algal diet grew at a rate statistically similar to those on a green algal diet [16]. Bezerra et al. [19] also found that a red algal diet is required for $A$. dactylomela Rang to secrete purple ink. The digestive gland of $A$. juliana also had pitted, medium electron dense granules and medium osmophilic granules (the latter probably starch). Both types of granules were found as well in A. californica when restricted to a green algal diet (Figure 1(b) compared to Figure 7(c) [16] and Figures 1(a) and 1(b) compared to Figure $7(\mathrm{a}, \mathrm{c})[12]$, resp.).

4.4. Presence of Rhodoplast Digestive Cells in Sea Hare Digestive Glands. The ultrastructure of rhodoplast digestive cells in A. parvula which produces purple and white ink by the same gland was similar to that of $A$. californica which releases only purple ink. Digestive glands and their rhodoplast digestive cells seem to have minimal ultrastructural variation between species and genera. Prince and Johnson [14] found major ultrastructural differences, however, between the ink glands of $A$. californica and D. dolabrifera.

4.5. Calcium Deposits. The form of calcium in the calcium carbonate deposits in the digestive gland of $D$. dolabrifera was probably not vaterite as this generally appears as one to several spherules in a cell [18]. In addition, the electron-dense submatrix (of mucopolysaccharides and proteins) in vaterite is radially arranged and appears as thin rods [18]. The submatrix in $D$. dolabrifera had a random organization and was composed of short globular units. The cells involved with calcium deposition in $D$. dolabrifera, furthermore, lacked sieve areas, a characteristic of calcium cells involved with active calcium accumulation [18].

4.6. Phylogenetic Implications. Two well-supported clades, one representing the subgenus Aplysia (including A.juliana) and one including the subgenus Varria with A. californica of subgenus Neoplysia nested within it, were recovered in a phylogenetic analysis of the genus Aplysia based on sequences of two mitochondrial genes [20]. The relationships of two representatives of subgenus Pruvotaplysia (including A. parvula) were not resolved but appear to be basal within the genus Aplysia. This phylogenetic hypothesis indicates that three of the species studied here represent a diversity of lineages within Aplysia.

Our study of the ultrastructure of the digestive gland from these representatives suggests that the most recent common ancestor of the genus Aplysia had similar digestive gland architecture. In addition, similar digestive gland ultrastructure was found in the sister group of Aplysia, Dolabrifera dolabrifera, which may indicate that the digestive gland was a trait of the common ancestor to these two genera. If the metabolism of the rhodoplast cell is indeed different in these two genera as suggested above, then this metabolic difference would have appeared after their divergence.

Medina et al. [20] suggest that white ink secretions and, therefore, the loss of a colored ink defense are a synapomorphy of the subgenus Aplysia based on their phylogenetic framework for the genus. In addition, the purple pigment of ink (APV) deters blue crab predators [13, 21]. According to Medina et al. [20] this loss of the ability to produce the defensive purple ink could cause members of this subgenus to be more vulnerable to predators, thereby increasing the potential role of the opaline gland's defensive function (see below). Prince and Johnson [14] and Bezerra et al. [19] found, however, that ink color can be diet related. Aplysia juliana produces white ink on a green algal diet but purple ink on a red algal diet. This confounds the hypothesis that the genus Aplysia has lost the antipredator purple inking function since A. juliana produces either white or purple ink depending on its diet.

Medina et al. [20] speculate that the defensive role of the opaline gland would increase with the loss of colored ink production in the subgenus, Aplysia. Ink color or pigment is not, however, the sole or perhaps even the most important defensive component of released ink. High molecular weight protein apparently synthesized by the ink gland [14] and other colorless or white compounds in ink elicit diverse responses of several predators of sea hares. These responses range from rejection to phagomimicry $[5,7,15,22]$ depending on the particular predator. Aplysia juliana contains julianin-S in its white ink [23] and it probably has antipredator properties similar to that of the high molecular weight protein isolated from purple ink of $A$. californica (i.e., escapin) and similar 
antimicrobial properties as demonstrated for escapin from $A$. californica, aplysianin-P from A. kurodai, or Aplysia punctata ink toxin from $A$. punctata (see [14] for a review). Ink, regardless of its white or purple color, has proteins and other compounds synthesized by the sea hare or derived from their algal diet, which can act to deter several predators.

An examination of the ultrastructure of the ink gland of representatives of the genus Aplysia should help determine both the color hierarchy for sea hare survival and the characteristics of the ink gland of the last common ancestor for the subgenus, Aplysia, and its sister group, Dolabrifera.

\section{Acknowledgments}

This research was supported in part by the Dauer Electron Microscopy Laboratory, Biology Department, University of Miami. The authors thank Ms. Lea Holingsworth, Kailua, HI, for the collection and maintenance of Dolabrifera dolabrifera; Dr. Kei-ichi Sakai, Chief Curator of Research and Education at the Noto Marine Center, and his assistant Mr. Yukimasa Higashide for the help in finding and collecting sea hares in Ishikawa Japan; Drs. Yoshihisa Shirahama and Shin Kubota of the Seto Marine Laboratory for providing housing and laboratory facilities for sea hare collecting there; and Dr. Barbara Whitlock for critical review of the paper.

\section{References}

[1] E. R. Kandel, Behavioral Biology of Aplysia. A Contribution to the Comparative Study of Opisthobranch Molluscs, W. H. Freeman, San Francisco, Calif, USA, 1979.

[2] T. G. Nolen, P. M. Johnson, C. E. Kicklighter, and T. Capo, "Ink secretion by the marine snail Aplysia californica enhances its ability to escape from a natural predator," Journal of Comparative Physiology A, vol. 176, no. 2, pp. 239-254, 1995.

[3] P. M. Johnson and A. O. D. Willows, "Defense in sea hares (Gastropoda, Opisthobranchia, Anaspidea): multiple layers of protection from egg to adult," Marine and Freshwater Behaviour and Physiology, vol. 32, no. 2-3, pp. 147-180, 1999.

[4] C. E. Kicklighter, S. Shabani, P. M. Johnson, and C. D. Derby, "Sea hares use novel antipredatory chemical defenses," Current Biology, vol. 15, no. 6, pp. 549-554, 2005.

[5] J. S. Prince, "Opaline gland ultrastructure in Aplysia californica (Gastropoda: Anaspidea)," Journal of Molluscan Studies, vol. 73, no. 2, pp. 199-204, 2007.

[6] R. R. Troxler, G. D. Offner, and T. R. Capo, "Structural studies on aplysioviolin,” Biological Bulletin, vol. 161, p. 339, 1981.

[7] P. M. Johnson, Multi-component chemical defense in sea hares (Gastropoda: Opisthobranchia): antipredator compounds act as both honest and deceptive signals to multiple predator species [Ph.D. thesis], University of Washington, Seattle, Wash, USA, 2002.

[8] H. Yang, P. M. Johnson, K.-C. Ko et al., "Cloning, characterization and expression of escapin, a broadly antimicrobial FAD-containing L-amino acid oxidase from ink of the sea hare Aplysia californica," Journal of Experimental Biology, vol. 208, no. 18, pp. 3609-3622, 2005.

[9] M. Yamazaki, K. Kimura, J. Kisugi, and H. Kamiya, "Purification of a cytolytic factor from purple fluid of a sea hare," FEBS Letters, vol. 198, no. 1, pp. 25-28, 1986.
[10] M. Yamazaki, K. Kimura, J. Kisugi, K. Muramoto, and H. Kamiya, "Isolation and characterization of a novel cytolytic factor in purple fluid of the sea hare, Aplysia kurodai," Cancer Research, vol. 49, no. 14, pp. 3834-3838, 1989.

[11] R. MacColl, J. Galivan, D. S. Berns, Z. Nimec, D. GuardFriar, and D. Wagoner, "The chromophore and polypeptide composition of Aplysia ink," Biological Bulletin, vol. 179, pp. 326331, 1990.

[12] J. Prince, T. G. Nolen, and L. Coelho, "Defensive ink pigment processing and secretion in Aplysia californica: concentration and storage of phycoerythrobilin in the ink gland," Journal of Experimental Biology, vol. 201, no. 10, pp. 1595-1613, 1998.

[13] M. Kamio, L. Nguyen, S. Yaldiz, and C. D. Derby, "How to produce a chemical defense: structural elucidation and anatomical distribution of aplysioviolin and phycoerythrobilin in the sea hare Aplysia californica," Chemistry and Biodiversity, vol. 7, no. 5, pp. 1183-1197, 2010.

[14] J. S. Prince and P. M. Johnson, "Ultrastructural comparison of Aplysia and Dolabrifera ink glands suggests cellular sites of antipredator protein production and algal pigment processing," Journal of Molluscan Studies, vol. 72, no. 4, pp. 349-357, 2006.

[15] C. D. Derby and J. F. Aggio, "The neuroecology of chemical defenses," Integrative and Comparative Biology, vol. 51, no. 5, pp. 771-780, 2011.

[16] L. Coelho, J. Prince, and T. G. Nolen, "Processing of defensive pigment in Aplysia californica: acquisition, modification and mobilization of the red algal pigment, r-phycoerythrin by the digestive gland," Journal of Experimental Biology, vol. 201, pp. 425-438, 1998.

[17] J. S. Prince, "A presumptive alphavirus in the gastropod mollusc, Aplysia californica," Bulletin of Marine Science, vol. 73, no. 3, pp. 673-677, 2003.

[18] J. S. Prince, M. J. Lynn, and P. L. Blackwelder, "White vesicles in the skin of Aplysia californica cooper: a proposed excretory function," Journal of Molluscan Studies, vol. 72, no. 4, pp. 405412, 2006.

[19] L. E. A. Bezerra, A. F. U. Carvalho, L. A. Barreira et al., "The relationship between seaweed diet and purple ink production in Aplysia dactylomela Rang, 1828 (Gastropoda: Opisthobranchia) from Northeastern Brazil," Journal of Shellfish Research, vol. 23, no. 2, pp. 381-386, 2004.

[20] M. Medina, T. M. Collins, and P. J. Walsh, "MtDNA ribosomal gene phylogeny of sea hares in the genus Aplysia (gastropoda, opisthobranchia, anaspidea): implications for comparative neurobiology," Systematic Biology, vol. 50, no. 5, pp. 676-688, 2001.

[21] M. Kamio, T. V. Grimes, M. H. Hutchins, R. van Dam, and C. D. Derby, "The purple pigment aplysioviolin in sea hare ink deters predatory blue crabs through their chemical senses," Animal Behaviour, vol. 80, no. 1, pp. 89-100, 2010.

[22] C. D. Derby, "Escape by inking and secreting: marine molluscs avoid predators through a rich array of chemicals and mechanisms," Biological Bulletin, vol. 213, no. 3, pp. 274-289, 2007.

[23] H. Kamiya, K. Muramoto, R. Goto, M. Sakai, Y. Endo, and M. Yamazaki, "Purification and characterization of an antibacterial and antineoplastic protein secretion of a sea hare, Aplysia juliana," Toxicon, vol. 27, no. 12, pp. 1269-1277, 1989. 

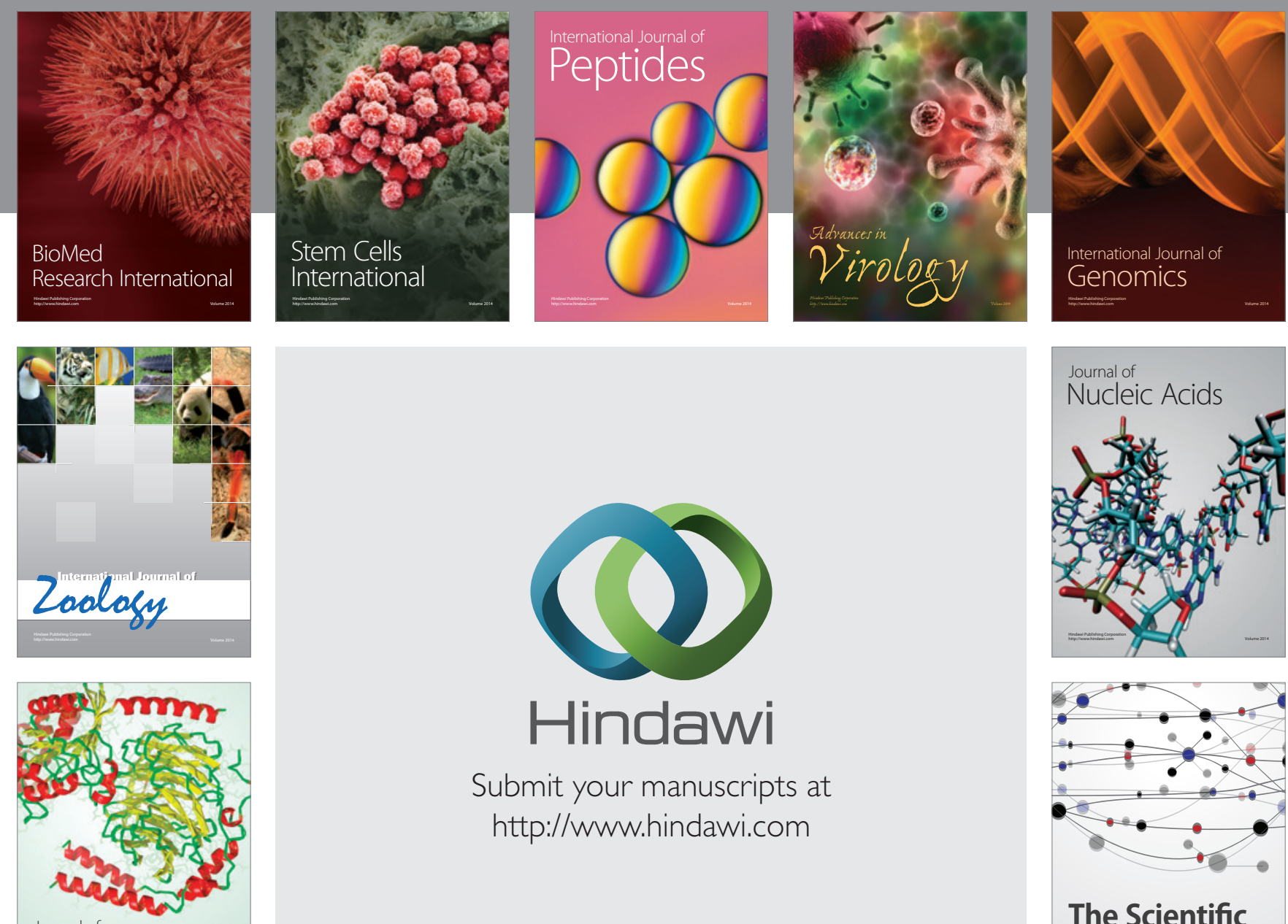

Submit your manuscripts at

http://www.hindawi.com

Journal of
Signal Transduction
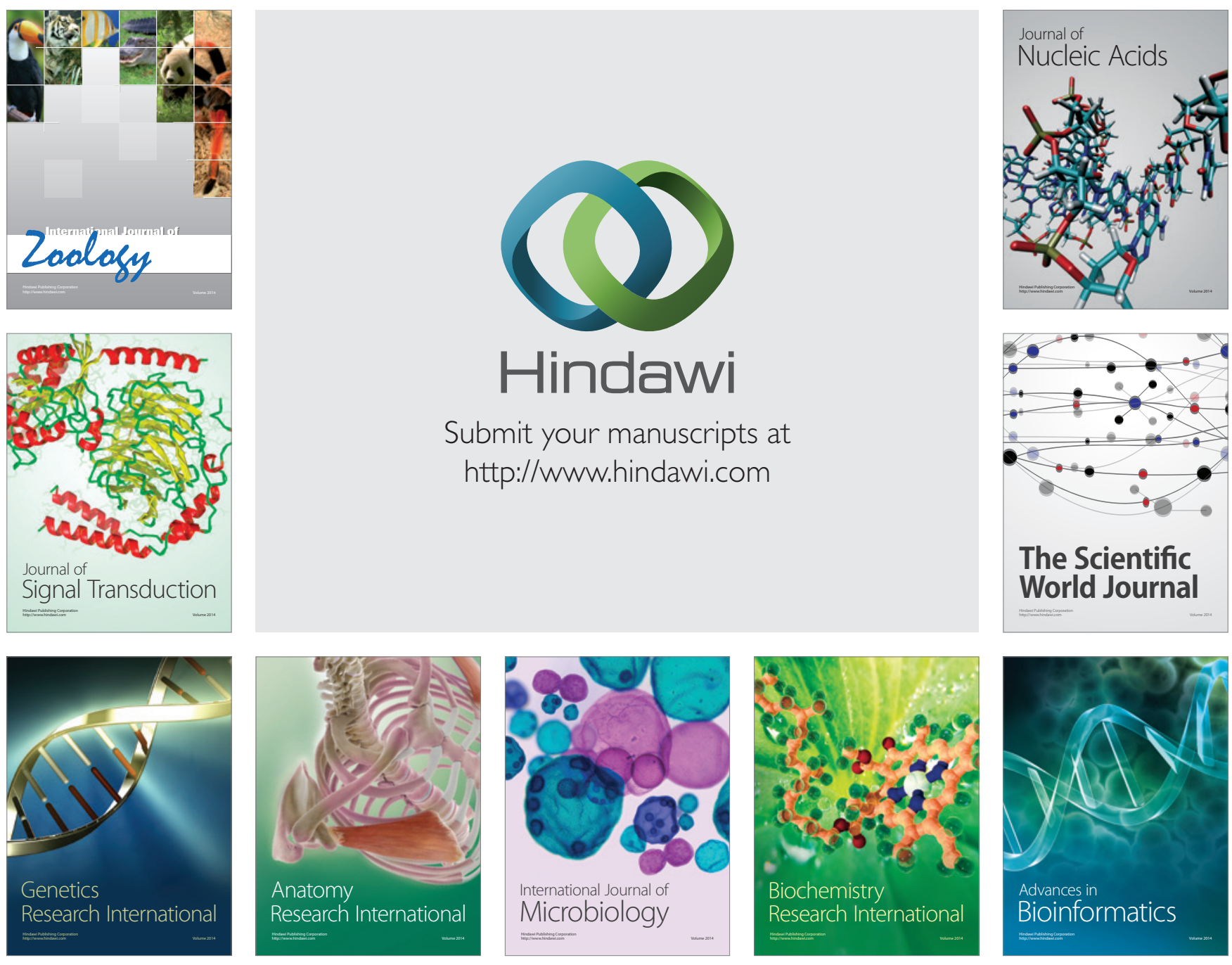

The Scientific World Journal
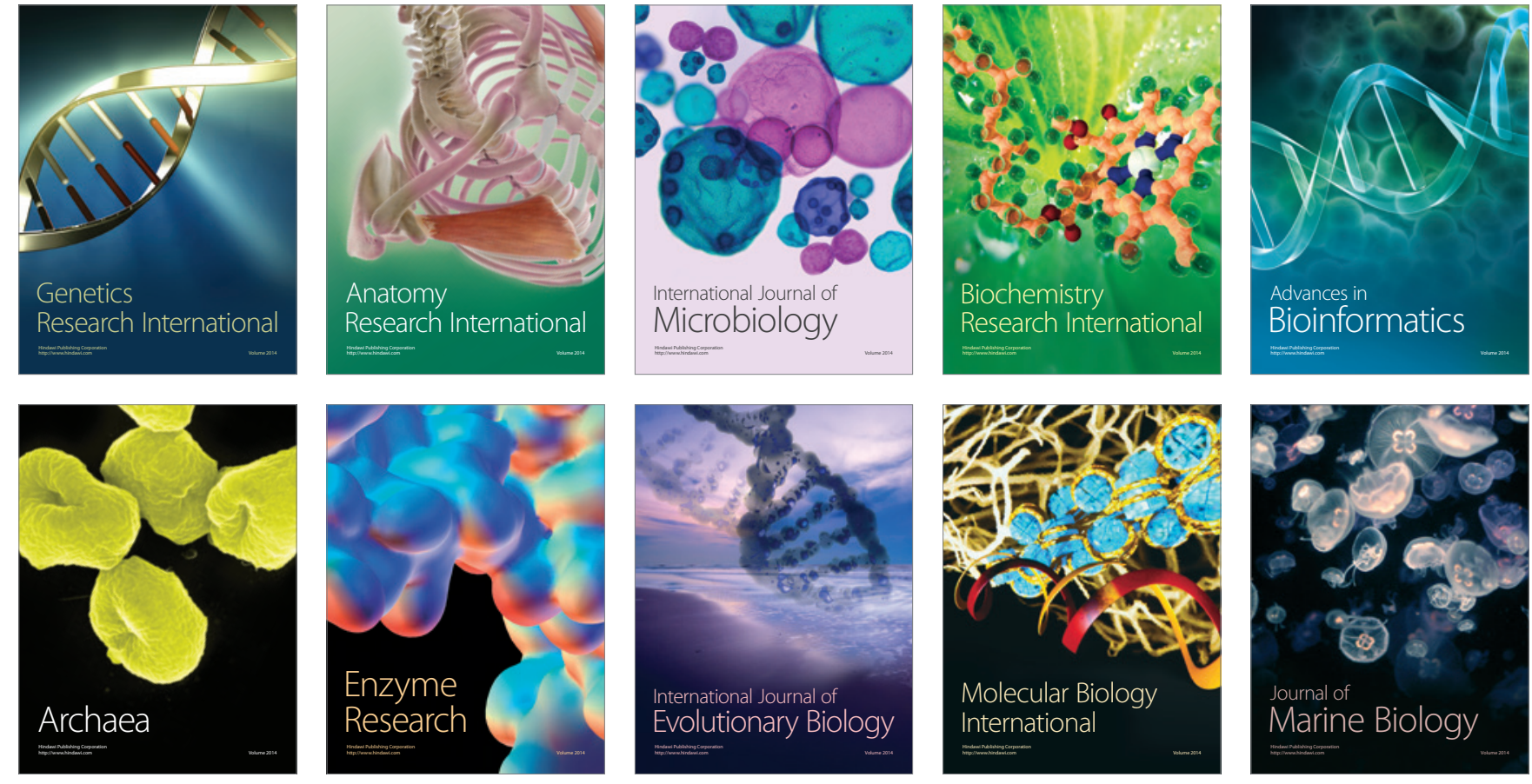